血壓降下性物質の研究 (第四報)

燐酸の血熋降下性飞就て

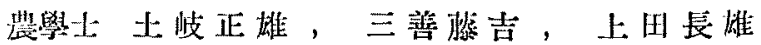

(昭和九年六月二十三日受理)

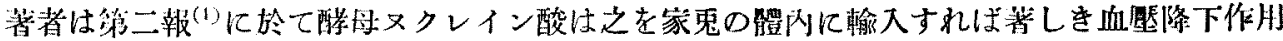

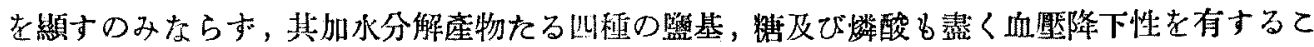
とを報告せり。

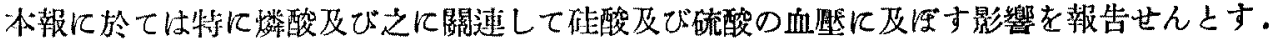

\title{
I. 燐酸の血壓降下作用
}

生體內の燐酸化合物は然機性監類としてヌは多種のエステルとして隨處に含有せらる。

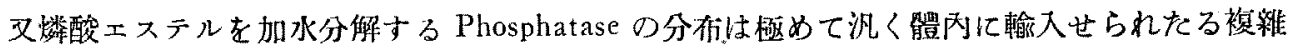

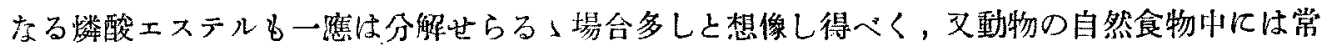
に多少の橉酸化合物を舍有せざるてとなし．

郎ち燐酸化合物は生體の常成分にしてからる物質を少量に生體內に輸入するてとに依り著し き作用を顯すべしとは期待し得べからざるに不拘，事實は甚だ著朋なる血堅降下作朋を呈する は前に報告せる如くにして燐酸の體內に於ける意義の甚炏微妙なるを思はしむ。

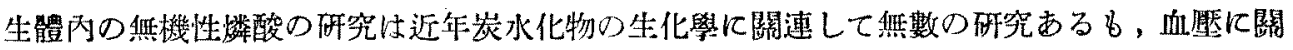

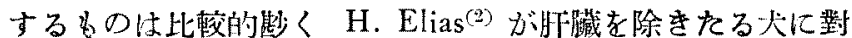

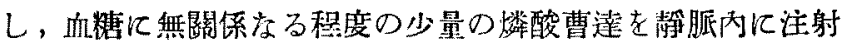

すれば高血壓及び Glucosurea を防遏すとの觀察をなせるが 此較的古きが如し.

\section{〔A〕無機性燐酸}

第二耀酸曹達を per $\mathrm{kg} 2 / 10,000 \mathrm{~mol}$. 種々なる方法にて 家鬼の體內に輸入し，其未稍盼壓の變化を倉矢氏法にて測定 したる結果を第一圖に示す。

用量を減じて $1 / 50,000 \mathrm{~mol}$. 以下となれば殖ど其作用を認 め得亦。

長期に互つて連續投與すれば血壓は濑次低下するも，數日

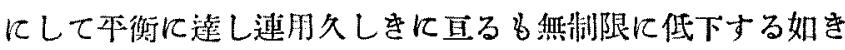
ことなく，中此後も相常長期䎲亘つて後作用の持續するを見 たり.
第一闻 $\mathrm{Na}_{2} \mathrm{HPO}_{4}$ Kaninchen per $\mathrm{kg}$. $2 / 10,000 \mathrm{~mol}$.

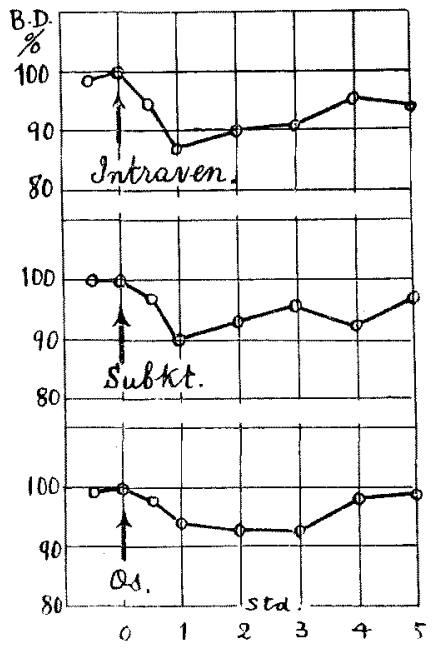




\section{〔B〕有機性燐酸化合物}

試 料

1. Na-glycero phosphate $\alpha$ 及び $\beta$.

- Na-glucose mono phosphate (1).

八 Phytin.

= 卵黃 Lecithin

ホ Na-Nucleate (酵母).

人 乾燥醉舟酒精抽出殘渣.

卜 䰷の精巣酒精抽出殘渣.

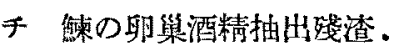

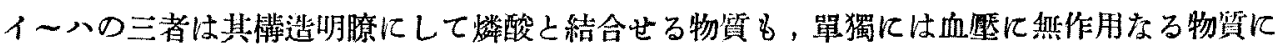
して試料方亦純粹存 $\mathfrak{b}$.

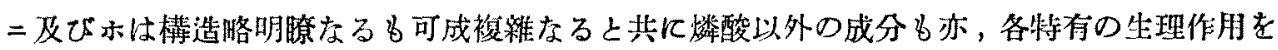

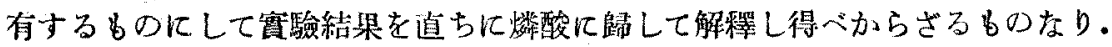

ヘーチの三者は勿論單一なる物質に非ざるも，單に会燐酸物質として試驗せるものなり。

これ等はんづれる燐酸含量を定量し，投與量は燐酸の mol. 數を標準とし體重一キロ當り 2/10,000 mol. 上定め，全例を通じて比較し得る經口投與の場合を熒二圖に示す。

第 三 圖

家鬼，經口投與，燐酸ざて䈏キ口 2/10,000 mol.

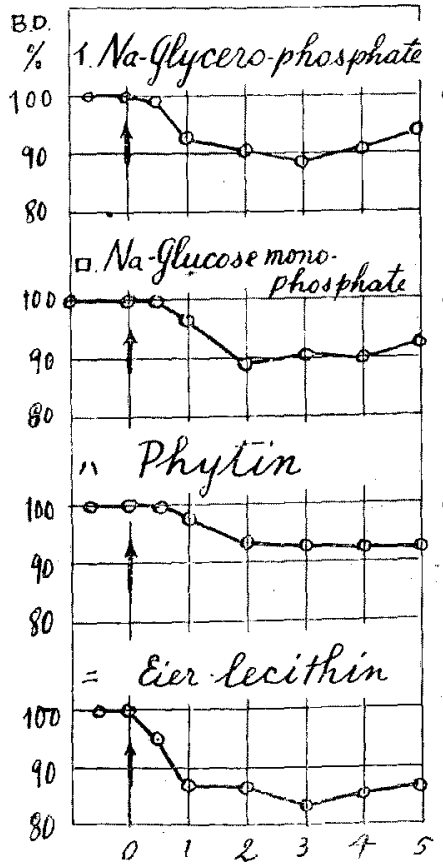

N. Na-hucleate

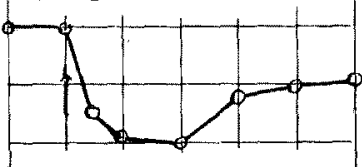

人乾燥醉姆酒精抽出残语

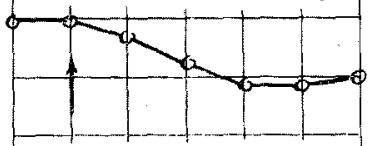

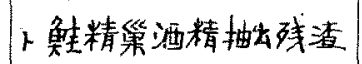
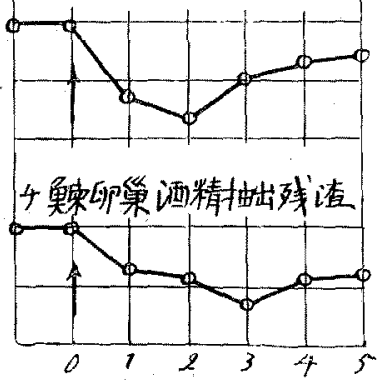
1. Na-glycerophosphate.

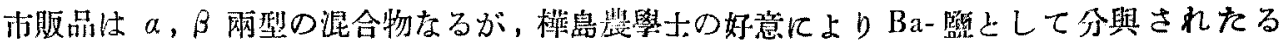

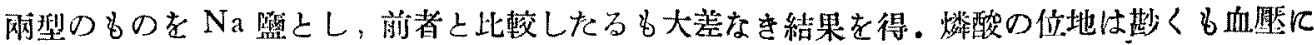
は然關係なるを知れり。

口. Na-glucose phosphate.

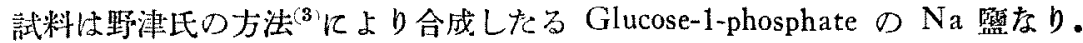

八. Phytin.

米綠より自製したるものにして逰離橉酸根の存在を認め得ざる艺精製したるものなり。

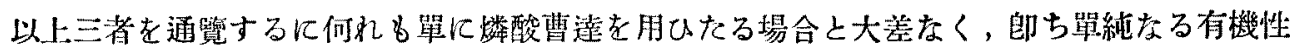

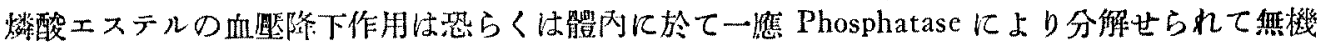
性燐酸監を與入ると同栐の絬果となるものならん。

二. 卵黃 Lecithin.

試料はメルク製にして狗諭純粹なるるのに非咭して不純なるPhosphatide の混合物と解釋す ベをるのなり。

Phosphatide には燐酸以外に著しき血盟降下性考有する祭基 Cholin，Monoethanolamin's (Amino ethylalcohol) 等を合さを以て圆に示す絬果は，直ちに燐酸の作用のみに歸するを得さ るも有力なる一因たるぺし。

ホ.酵母ヌクレイン酸曹達。

第二報に於て酵母ヌクレイン酸曹達は其投與法の如何に不拘著しき血盟降下作用を現はすを

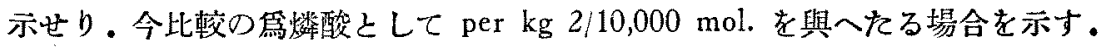

即ち燐酸のみの場合より著しく作用大なるは他に種火の血勧降下性物質を含むを以て，當然 なるも燐酸が有力なる一因をるは疑ふでからず。

人. 乾燥酵母酒精抽出殘渣.

ト . 薢の精森酒精抽出残渣.

チ.䱨の卵巢酒精抽出殘渣.

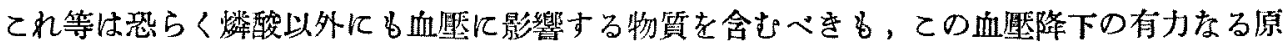
因の一つとして燐酸考考虑の外に置くを得禾。

てれ等の試料を酒精にて抽出したる理由は著者の第一報 ${ }^{(5)}$ 公照されたし。

以上を要するに燐酸は如何なる形熊にありても之を生體內に輸大すれば，著しき血堭降下作 用老顯すを知る。

\section{[C]燐酸の藥理學的觀察}

(i) 寻性.

1. 第二燐酸曹造。

咥大なる致死量と謂ぷく，生體の常成分たるととょり當然首肯し得べし。 
皮下注射最少致死量（當キロ）

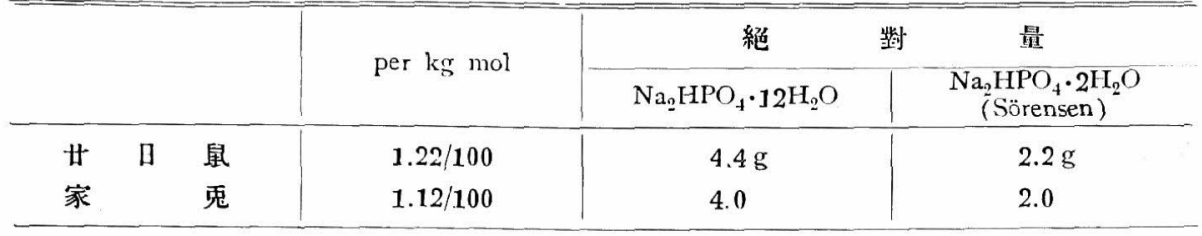

第三圖 燐酸曹澾致死量以上没下注射

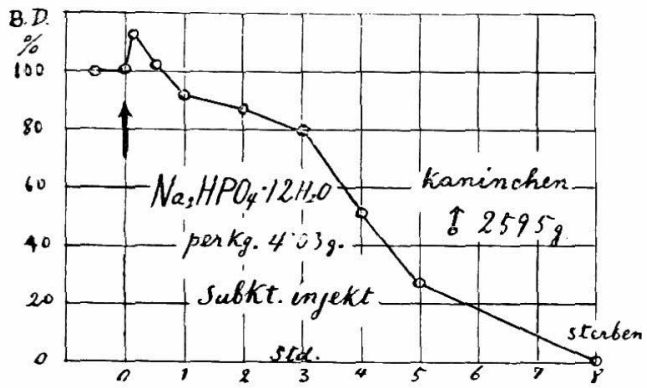

ロ・グリセロ燐酸曹達。

比日鼠皮下注射最少致死量は $2.17 / 100$ mol. (絕對量 $4.4 \mathrm{~g}$ ) として著しく毒情小な り . ての理由は $\mathrm{Na}_{2} \mathrm{HPO}_{4}$ の如く體內に於 て直ちにイオン間の午衍に變動を與へず徐 々に分解さる」爲なるへしし。

班死量以上の大量の $\mathrm{Na}_{2} \mathrm{HPO}_{4}$ 老家鬼 の皮下に注射したる場合の血壓曲線を第三 圖に示す。

(ii) 心歲几對する作用.

金線蛙摘出心臟に種々の濃度の燐酸曹達リンダルを灌流したる場合の記錄を第凹圖に示す。 第四圖

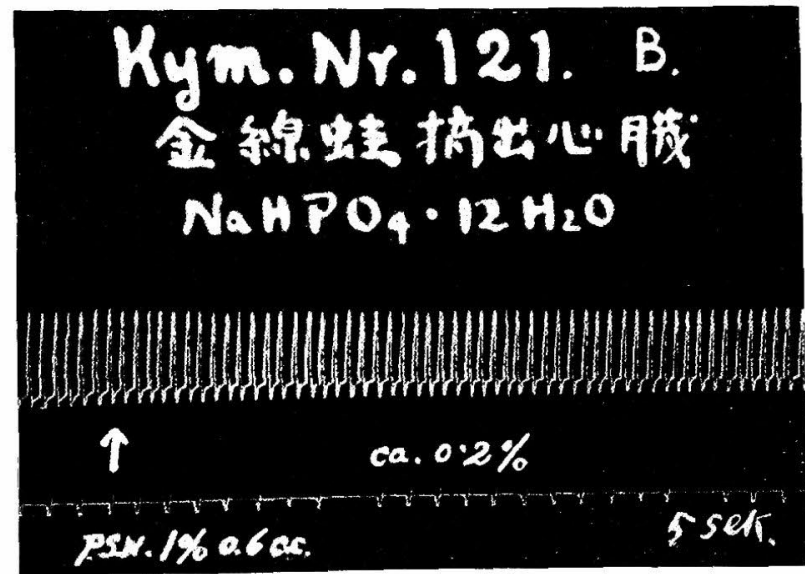

$\operatorname{ca} .0 \cdot 5 \%$

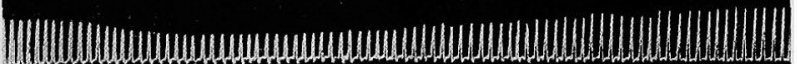

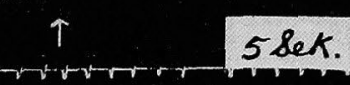

PSN $5 \% 0.3$ ce in Ringer 3 U. 


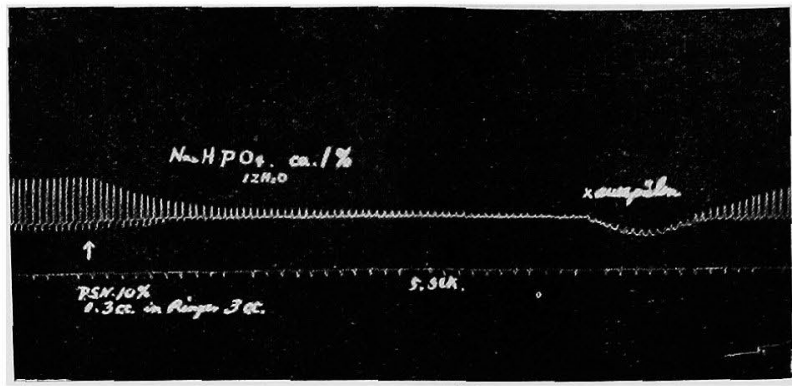

$\mathrm{Na}_{2} \mathrm{HPO}_{4} ・ 12 \mathrm{H}_{2} \mathrm{O}$ として約 $0.5 \%$ にして僅かに抑制せられ $1 \%$ の高浱度に於て初めて殆ど停 止するも，之をリンゲルにて洗へば再び恢復す。

(iii） 未梢血管飞對する影響。

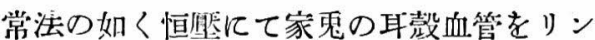
ダルにて灌流し置き，次で $1 \% の \mathrm{Na}_{2} \mathrm{HPO}_{4}$ ・ $12 \mathrm{H}_{2} \mathrm{O}$ を含むリンダルと䐕換すれば流下滴 數は著しく增加し，再びリンゲルと置換すれ ば原滴數に復する狀態を第五圖に示す。

グリセロ燐酸ソーダについて\&同㥞の結果 を得をり。

即ち末梢血管の擴大を語り，血雁降下の作 用轉機を喑示するものなり。

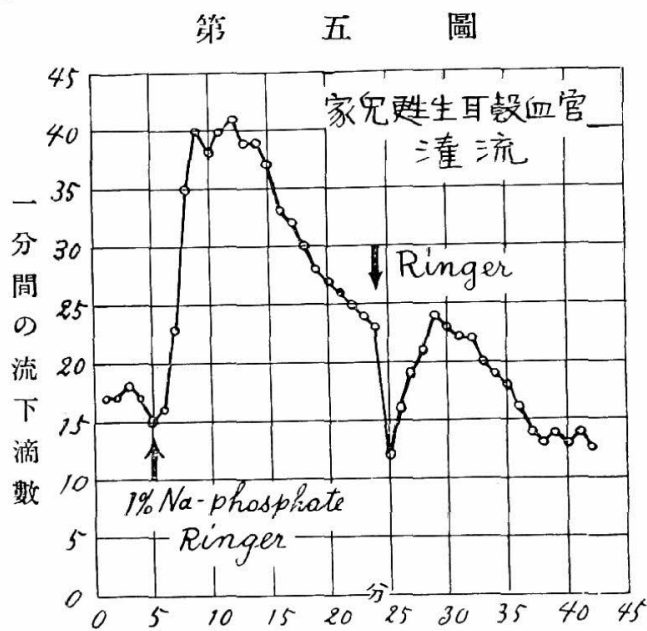

\section{II．硅酸及び硫酸つ血壓に對する作用}

既に臨床的に用ひられつ」ある血聮降下劑中に住酸曹達を主成分とすると稱するものあり。 故に陚に $\mathrm{Na}_{2} \mathrm{Si}_{2} \mathrm{O}_{7} \cdot 2 \mathrm{H}_{2} \mathrm{O}^{*}$ を用ひて試驗せり。

ての水溶液は可成强きアルカリ性なるt在以て砫酸ゲルを生ぜざる程度に dil. $\mathrm{HCl}$ を加へ可 及的反應老修正し $\mathrm{SiO}_{2}$ 老定量し, $\mathrm{SiO}_{2}$ として per kg 2/10,000 mol。蒙鬼の體內に輸入し をる結果をは第六圖に示す。

又一方第二報に於て Cytosinsulfat に關連して述べをる如く $\mathrm{Na}_{2} \mathrm{SO}_{4}$ \&亦血埾降下性あり。 第六圖 $\mathrm{B}$ は特に比較の爲 $\mathrm{Na}_{2} \mathrm{SO}_{4}$ を家鬼に per $\mathrm{kg} 2 / 10,000 \mathrm{~mol}$. 與へたる例なり.

以上砫酸, 燐酸及び硫酸の三者を通覽するに Si，P，S は原子番號相隣し又, 酸としての三

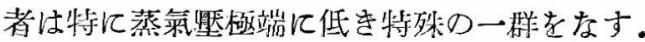

一方之を生化學的に見るに燐酸に乏しき場合，膠狀礁酸を施與するととに低り著しく稙物の

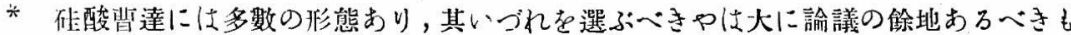
何れも其水溶液は强アルカリ性にてて之を中和すれば硅酸ゲルを生ず。本目驗に $\mathrm{Na}_{2} \mathrm{Si}_{2} \mathrm{O}_{7}$ ・ $2 \mathrm{H}_{2} \mathrm{O}$ を選びけっるは單に最も純粹なる市販品を得易き點による。この外に $\mathrm{Na}_{2} \mathrm{SiO}_{3} \cdot 6 \mathrm{H}_{2} \mathrm{O} に$

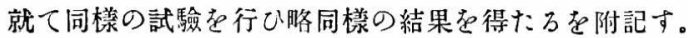


第

六圆

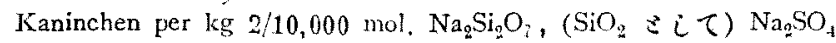
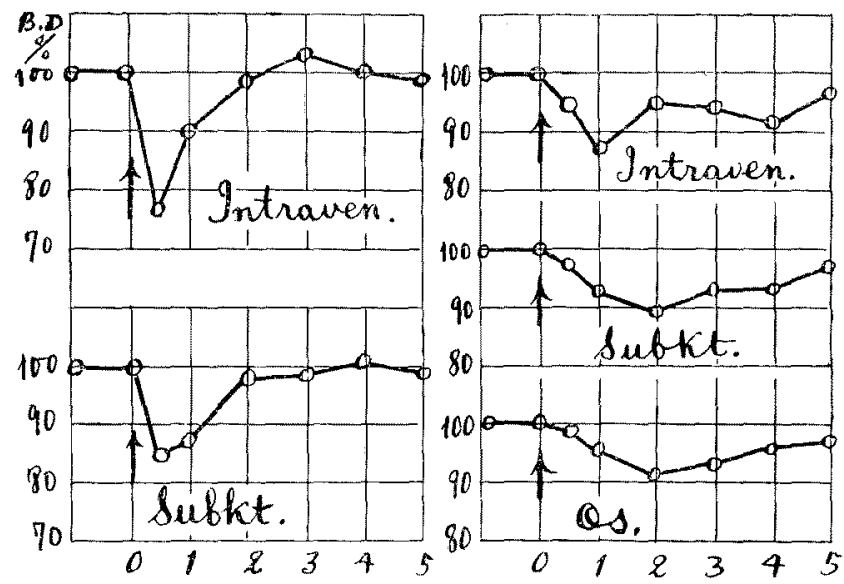

生青を良好ならしめ得との Lemmermann ${ }^{(6)}$ の筫驗にして真なりとせば燐酸と碓酸とは勘くる 植物生理に於ては密接索る關連を有するもの之㳯ふへし。

又自然界に於て多數の炭水化物の燐酸エステル（特に澱粉の Amylopectine）發見せらる」が

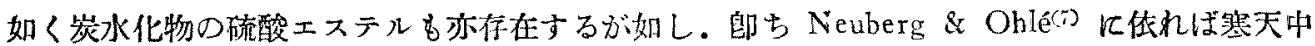
には常に硫酸存在し，Samec＆Isajevičc(s) に依れば寒天の主成分は Gelose の硫酸エステルな らんと云ふ。

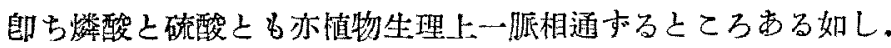

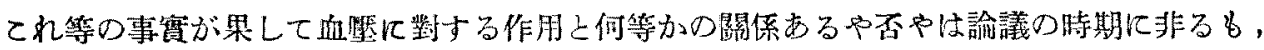

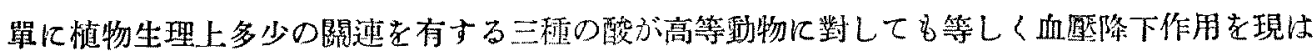
す事實を指摘するに止む。

總 括

（1）燐酸は其形態の如何に不拘家忽の血堅を降下せしさる作用すり。

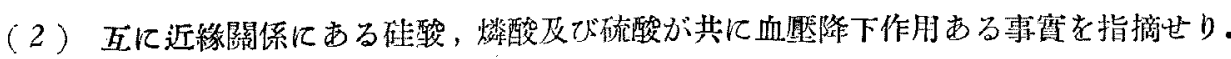

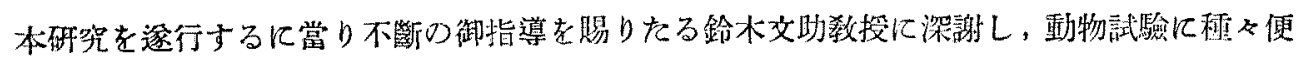
宜を與へられたる三共株式會社製造部長湯泚孫比に感謝す。

於京都帝大 化學研究所（土怶）

\section{文獻}

（1）著者：農化，vol，9，705 714，(炤和八年).

(2) II. Elias: Biochem. Z., 138, 299 306, (1923).

(3) S. Komatsu \& R. Nodzu: Memoirs of the College of Science, Kyoto Imp. Univ, Series A., vol. VII, No. 6, (1924). 


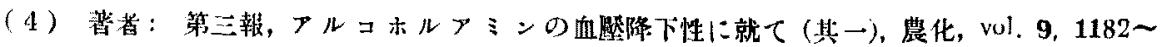
1192, (1933), 砦炤.

( 5 ) 桨者: 㖘化, vol. 9, 625 631, (1933).

(6) Lemmermann: Z. Pflanzenernähr. Diingung (A) 1, 185 255, (1922).

(7) Neuberg \& Ohlé: Biochem. Z, 125, 311, (1921).

( 8 ) Samec \& Isajevič: Koll. Chem, Reih., 16, 285, (1922). 